\title{
Väkirehuruokinnan intensiteetti ja valkuaisrehulisäys ayrshire-sonnien kasvatuksessa - vaikutukset tuotantoon ja tuotannon talouteen
}

\author{
Pekka Pihamaa $^{1)}$, Lauri Juntti ${ }^{1)}$, Arto Huuskonen ${ }^{2)}$, Janne Kiljala ${ }^{2)}$, Erkki Joki-Tokola ${ }^{2)}$ ja Kyösti Pieto- \\ la ${ }^{1)}$ \\ ${ }^{1)}$ MTT, Taloustutkimus. Luutnantintie 13,00410 Helsinki, etunimi.sukunimi@mtt.fi \\ ${ }^{2)}$ MTT, Pohjois-Pohjanmaan tutkimusasema. Tutkimusasemantie 15, 92400 Ruukki, \\ etunimi.sukunimi@mtt.fi
}

\section{Johdanto}

Suomessa on koko EU-jäsenyyden ajan keskusteltu väkirehun käyttömääristä lihanautojen ruokinnassa. Keskusteluun ovat osallistuneet sekä biologisen puolen (Huhtanen 1998) että taloustutkijat (Pihamaa \& Pietola 2001, Ryhänen ym. 2002). Valkuaislisän tarvetta lihanautojen ruokinnassa on tutkittu Suomessa useassa kasvatuskokeessa (Huhtanen ym. 1985, Aronen 1990, 1991, Joki-Tokola 1991, 1996, Aronen ym. 1992), mutta valkuaislisän vaikutusta taloudelliseen ylijäämään ei ole aiemmissa tutkimuksissa vielä täysin selvitetty.

MTT:n toteuttamassa laajassa tutkimushankkeessa selvitetään, miten väkirehuruokinnan voimakkuus vaikuttaa lihanautojen loppukasvatuksessa. Tutkimuksessa naudat kasvatetaan totuttua suurempiin teuraspainoihin. Kokeilla halutaan selvittää eri väkirehutasojen ja valkuaislisän vaikutusta tuotannon taloudelliseen kannattavuuteen, eläinten kasvuun, rehun syöntiin ja ruhojen teuraslaatuun. Tutkimushanke sisältää kolme ruokintakoetta eri väkirehutasoilla. Tässä artikkelissa esitellään ensimmäisestä ruokintakokeesta saatuja tuotanto- ja taloustuloksia.

\section{Aineisto ja menetelmät}

Lihanautojen kasvatuskoe toteutettiin Maa- ja elintarviketalouden tutkimuskeskuksen PohjoisPohjanmaan tutkimusasemalla. Koe alkoi maaliskuussa 2002 ja päättyi vuoden 2003 alussa, jolloin koe-eläimet teurastettiin. Teuraspainotavoite oli $350 \mathrm{~kg}$. Koe-eläimet (30 kpl ayrshire-rotuisia sonneja) olivat Pohjois-Pohjanmaan tutkimusasemalla välikasvatettuja sonneja, jotka olivat $6-7$ kk:n ikäisiä kokeen alkaessa. Kokeen alussa eläimet siirrettiin parsinavettaan, jolloin ne kytkettiin parteen. Järjestelyllä saatiin eläinkohtaisia havaintoja. Eläimet ryhmiteltiin kokeen alussa elopainon perusteella neljään blokkiin, joista ne sijoitettiin satunnaisesti eri ruokinnoille. Koejärjestely oli 3 x 2 faktoriaalinen koe, jossa vertailtavina koetekijöinä olivat väkirehuruokinnan intensiteetti ja ruokinnan valkuaisrehutäydennys. Kokeen kolme väkirehutasoa olivat 30,50 ja $70 \%$ päivittäisestä kuiva-aineen syönnistä. Valkuaisrehuruokinnan vertailtavana koetekijänä oli rypsilisäys: sonnit saivat väkirehuna joko pelkkää ohraa tai ohran ja rypsin seosta. Rypsilisällä väkirehun raakavalkuaispitoisuus nostettiin 16 - 17 prosenttiin. Sonnit saivat vapaasti seosrehua, joka sisälsi edellä mainitussa suhteessa karkearehua ja väkirehua. Karkearehuna oli nurmisäilörehu. Suoritettavalla koejärjestelyllä saatiin selville rehun kulutus eläinkohtaisesti. Ruhon laatu määriteltiin luokittelemalla ruhojen lihakkuus ja rasvaisuus EUROPluokituksen mukaisesti. Ruokinnoista määritettiin ravintoaineiden näennäinen in vivo -sulavuus AIAmenetelmällä (Keulen ja Young 1977). Sulavuuskokeen kestoaika oli viisi vuorokautta, ja sen aikana kerätyt rehu- ja sontanäytteet analysoitiin MTT:n Eläinravitsemuksen laboratoriossa Jokioisilla. Tuotanto- ja taloustulosten tilastollinen käsittely tehtiin SAS-ohjelmiston varianssianalyysillä. Testauksen koemalli oli lohkoittain satunnaistettu koe.

Kasvatuskokeen rehunkäyttö- ja teurastulosten perusteella tehtiin taloudelliset laskelmat. Taloudelliset laskelmat tehtiin ylijäämälaskelmina, joissa lihasta ja tuista saatavista tuotoista on vähennetty ruokinnan kustannukset. Laskelmat on tehty kesän 2003 hinta- ja tukitasoja käyttäen. Väkirehujen hinnoittelu perustuu markkinahintoihin. Säilörehun hinta on määritelty vuosien 2000 ja 2001 Hilaaineiston perusteella. Tukitasot on poimittu tukien hakuoppaasta (MMM 2003). Ylijäämä on laskettu sekä B- että C2 -tukialueelle. Laskelmissa käytetyt hinnat ja tuet on raportoitu liitteessä 1.

\section{Tulokset ja tulosten tarkastelu}

\section{Tuotantotulokset ja tulosten tarkastelu}

Kokeessa käytetty nurmisäilörehu sisälsi kuiva-ainetta keskimäärin $274 \mathrm{~g} \mathrm{~kg}^{-1}$, raakavalkuaista $156 \mathrm{~g}$ $\left(\mathrm{kg} \mathrm{ka}^{-1}\right.$ ja NDF-kuitua $541 \mathrm{~g}(\mathrm{~kg} \mathrm{ka})^{-1}$. Säilörehun säilönnällinen laatu oli hyvä, D-arvo 67, rehuyksikköarvo 0,91 ry $\left(\mathrm{kg} \mathrm{ka}^{-1}\right.$ ja syönti-indeksi 96. Ohran keskimääräinen kuiva-ainepitoisuus oli $902 \mathrm{~g}$ 
$\mathrm{kg}^{-1}$, raakavalkuaispitoisuus $128 \mathrm{~g}\left(\mathrm{~kg} \mathrm{ka}^{-1}\right.$, hehtolitrapaino $63 \mathrm{~kg} \mathrm{~h}^{-1}$ ja rehuyksikköarvo $1,14 \mathrm{ry}(\mathrm{kg}$ $\mathrm{ka}^{-1}$. Kokeessa käytetty rypsirouhe sisälsi kuiva-ainetta $890 \mathrm{~g} \mathrm{~kg}^{-1}$ ja raakavalkuaista $386 \mathrm{~g}(\mathrm{~kg} \mathrm{ka})^{-1}$.

Sonnien kokonaiskuiva-aineensyönnissä ei ollut tilastollisesti merkitseviä eroja eri ruokintaryhmien välillä. Keskimääräinen kuiva-aineensyönti kokeen aikana oli $9,08 \mathrm{~kg} \mathrm{ka} \mathrm{d}^{-1}$. Eläinten syömät kuiva-ainemäärät eri ruokinnoilla on esitetty taulukossa 1 . Sonnien elopaino oli kokeen alussa keskimäärin $275 \mathrm{~kg}$. Dieetin väkirehuprosentti vaikutti merkitsevästi eläinten kasvunopeuteen (taulukko 1). Voimakkaimmalla väkirehuruokinnalla (70 \%) olleet sonnit saavuttivat tavoitellun teuraspainon keskimäärin 16,5 kuukauden iässä, $50 \%$ :n väkirehutasolla tavoiteteuraspaino saavutettiin 17,5 kuukauden iässä ja 30 \%:n väkirehutasolla 18,5 kuukauden iässä. Rypsilisällä ei ollut tilastollisesti merkitsevää vaikutusta eläinten kasvuun.

Teurastuloksiin väkirehun määrällä tai koostumuksella ei todettu olevan vaikutusta. Korkeasta teuraspainosta huolimatta ruhojen rasvoittuminen ei muodostunut ongelmaksi. Ruhot olivat ohut- tai keskirasvaisia eli niiden EUROP-luokat olivat 2 ja 3. Ruokinnassa käytetty väkirehutaso ei näin ollen tässä kokeessa vaikuttanut ruhojen rasvoittumiseen. Kokeen tulosten perusteella myös ay-sonneja pystytään kasvattamaan totuttua suurempiin teuraspainoihin ilman merkittävää ruhojen rasvoittumista.

Väkirehun osuuden lisääminen paransi merkitsevästi dieetin kuiva-aineen ja orgaanisen aineen sulavuutta, koska ohran sulavuus oli nurmisäilörehua parempi. Dieetin NDF-kuidun sulavuus heikkeni, kun väkirehun osuutta rehuannoksessa lisättiin. Syynä tähän on todennäköisesti kuidun sulatusnopeuden hidastuminen pötsin $\mathrm{pH}: n$ laskun seurauksena, sillä happamuuden lisääntyminen inhiboi pötsin sellulolyyttisten mikrobien toimintaa (Huhtanen ja Jaakkola 1994).

Taulukko 1. Sonnien kasvu, rehun kulutus, teurastulokset ja ruokintojen näennäinen in vivo -sulavuus eri väkirehuruokinnoilla.

\begin{tabular}{|c|c|c|c|c|c|c|c|c|c|c|}
\hline \multirow{2}{*}{$\begin{array}{l}\text { Väkirehutaso (V) } \\
\text { Rypsilisä (L) }\end{array}$} & \multicolumn{2}{|c|}{$30 \%$ dieetistä } & \multicolumn{2}{|c|}{$50 \%$ dieetistä } & \multicolumn{2}{|c|}{$70 \%$ dieetistä } & \multirow{2}{*}{ SEE $^{2)}$} & \multicolumn{3}{|c|}{ Merkitsevyys ${ }^{1)}$} \\
\hline & $\mathbf{E i}$ & On & $\mathbf{E i}$ & On & $\mathbf{E i}$ & On & & $\mathbf{V}$ & $\mathbf{L}$ & $\mathbf{V} * \mathbf{L}$ \\
\hline $\mathrm{n}$ & 4 & 5 & 5 & 4 & 5 & 4 & & & & \\
\hline \multicolumn{11}{|l|}{ Syönti, kg ka d ${ }^{-1}$} \\
\hline säilörehu & 6,11 & 6,45 & 4,78 & 4,67 & 2,62 & 2,95 & 0,39 & $* * *$ & & \\
\hline väkirehu & 2,58 & 2,69 & 4,62 & 4,52 & 5,91 & 6,60 & 0,30 & $* * *$ & o & $*$ \\
\hline yhteensä & 8,69 & 9,13 & 9,41 & 9,19 & 8,53 & 9,55 & 0,65 & & & \\
\hline \multicolumn{11}{|l|}{ Sonnien kasvu, $\mathrm{g} \mathrm{d}^{-1}$} \\
\hline päiväkasvu & 1054 & 1108 & 1211 & 1228 & 1258 & 1365 & 136,9 & $* *$ & & \\
\hline nettokasvu & 563 & 594 & 636 & 663 & 697 & 766 & 64,9 & $* * *$ & & \\
\hline \multicolumn{11}{|l|}{ Teurastulokset } \\
\hline teuraspaino, $\mathrm{kg}$ & 337 & 344 & 339 & 352 & 344 & 370 & 20,4 & o & & \\
\hline teurasprosentti, \% & 52,0 & 52,1 & 51,6 & 52,4 & 53,1 & 53,7 & 1,41 & $\mathrm{O}$ & & \\
\hline lihakkuus $^{3)}$ & 4,25 & 4,60 & 4,80 & 4,75 & 5,00 & 5,25 & 0,83 & & & \\
\hline rasvaisuus ${ }^{4)}$ & 2,75 & 2,60 & 3,00 & 3,00 & 2,80 & 2,75 & 0,61 & & & \\
\hline \multicolumn{11}{|c|}{ In vivo -sulavuus, \% } \\
\hline kuiva-aine & 73,8 & 73,2 & 75,1 & 75,2 & 77,6 & 76,4 & 1,82 & $* * *$ & & \\
\hline orgaaninen aine & 75,4 & 75,1 & 77,0 & 77,3 & 79,2 & 78,4 & 1,79 & $* * *$ & & \\
\hline raakavalkuainen & 68,6 & 74,2 & 67,8 & 77,8 & 71,6 & 78,8 & 3,27 & & $* * *$ & \\
\hline NDF-kuitu & 66,4 & 66,9 & 63,5 & 64,4 & 58,3 & 60,2 & 3,13 & $* * *$ & & \\
\hline
\end{tabular}

) o $\mathrm{p}<0,10 ; * \mathrm{p}<0,05 ; * * \mathrm{p}<0,01 ; * * * \mathrm{p}<0,001 .{ }^{2)}$ Estimaatin keskivirhe.

${ }^{3)}$ EUROP-luokitus: $\mathrm{O}-=4, \mathrm{O}=5, \mathrm{O}+=6 .{ }^{4)}$ EUROP-luokitus: $1=$ rasvaton, $2=$ ohutrasvainen, $3=$ keskirasvainen.

\section{Taloustulokset ja tulosten tarkastelu}

Lihasonnia kohti lasketut taloustulokset on esitelty loppukasvatuskauden osalta taulukoissa 2 ja päivää kohti laskettu taloudellinen ylijäämä taulukossa 3. Lisäksi koko kasvatuskauden taloudellinen ylijäämä eläintä kohti on raportoitu liitteessä 1. Väkirehun osuuden lisääminen dieetissä lisää lihasonnin kasvatuksesta saatavan taloudellisen ylijäämän määrää. Väkirehun osuuden lisääminen on tilastollisesti merkitsevä, kun säilörehu hinnoitellaan täyden tuotantokustannuksen mukaan. Kun säilörehu hinnoitellaan muuttuvien kustannusten mukaan, ruokintojen välinen ero ei ole enää tilastollisesti merkitsevä. Rypsilisä ja yhdysvaikutus eivät olleet tilastollisesti merkitseviä. Säilörehun hinnoittelu muuttuvien kustannuksien mukaan pienentää eri ruokintaryhmien välisiä absoluuttisia eroja. Loppukasvatuksessa ylijäämä eläintä kohti vaihteli, kun säilörehu hinnoiteltiin täyden tuotantokustannuksen mukaan välillä 
36-306 euroa. Kun säilörehu hinnoiteltiin muuttuvien kustannusten mukaan ylijäämä vaihteli välillä 223-380 euroa.

Taulukko 2. Loppukasvatuksessa taloudellinen ylijäämä sonnia kohti

\begin{tabular}{|c|c|c|c|c|c|c|c|c|c|c|}
\hline \multirow{2}{*}{$\begin{array}{l}\text { Väkirehu taso (V) } \\
\text { Rypsilisä (L) }\end{array}$} & \multicolumn{2}{|c|}{$30 \%$ dieetistä } & \multicolumn{2}{|c|}{$50 \%$ dieetistä } & \multicolumn{2}{|c|}{$70 \%$ dieetistä } & \multirow[b]{2}{*}{ SEM $^{2}$} & \multicolumn{3}{|c|}{ Merkitsevyys $^{1}$} \\
\hline & Ei & On & Ei & On & $\mathbf{E i}$ & On & & $\mathbf{V}$ & $\mathbf{L}$ & $\mathbf{V} * \mathbf{L}$ \\
\hline \multicolumn{11}{|l|}{ B-tukialue } \\
\hline Säilörehun hinta 1 & 70,8 & 36,9 & 123,3 & 106,0 & 260,9 & 234,5 & 5,72 & $*$ & & \\
\hline Säilörehun hinta 2 & 223,1 & 237,8 & 264,3 & 238,2 & 335,3 & 313,2 & 15,3 & & & \\
\hline \multicolumn{11}{|l|}{ C2-tukialue } \\
\hline Säilörehun hinta 1 & 124,1 & 90,2 & 172,6 & 155,3 & 306,3 & 280,0 & 5,72 & $*$ & & \\
\hline Säilörehun hinta 2 & 276,4 & 291,1 & 313,6 & 287,5 & 380,7 & 358,6 & 15,3 & & & \\
\hline
\end{tabular}

1) o $\mathrm{p}<0,10 ;{ }^{*} \mathrm{p}<0,05 ; * * \mathrm{p}<0,01 ; * * * \mathrm{p}<0,001 .{ }^{2)}$ Keskiarvon keskivirhe (Standard error of mean).

Taloudellinen ylijäämä päivää kohti koko kasvatuskaudella on raportoitu taulukossa 3. Ruokintojen edullisuusjärjestys ei muuttunut, kun siirryttiin eläintä kohti lasketusta ylijäämästä päivää kohti laskettuun ylijäämään. Väkirehun osuudella dieetistä oli tilastollisesti merkitsevä vaikutus molemmilla säilörehun hinnoittelutavoilla. Eläintä kohti laskettaessa väkirehun määrä oli merkitsevä vain, kun säilörehu hinnoiteltiin täyden tuotantokustannuksen mukaan.

Taulukko 3. Loppukasvatuksessa sonnien taloudellinen ylijäämä päivää kohti

\begin{tabular}{|c|c|c|c|c|c|c|c|c|c|c|}
\hline \multirow{2}{*}{$\begin{array}{l}\text { Väkirehu taso (V) } \\
\text { Rypsilisä (L) }\end{array}$} & \multicolumn{2}{|c|}{$30 \%$ dieetistä } & \multicolumn{2}{|c|}{$50 \%$ dieetistä } & \multicolumn{2}{|c|}{$70 \%$ dieetistä } & \multirow[b]{2}{*}{ SEM $^{2}$} & \multicolumn{3}{|c|}{ Merkitsevyys ${ }^{1}$} \\
\hline & $\mathbf{E i}$ & On & Ei & On & $\mathbf{E i}$ & On & & $\mathbf{V}$ & $\mathbf{L}$ & $\mathbf{V} * \mathbf{L}$ \\
\hline \multicolumn{11}{|l|}{ B-tukialue } \\
\hline Säilörehun hinta 1 & 0,18 & 0,10 & 0,35 & 0,30 & 0,79 & 0,71 & 0,014 & $*$ & & \\
\hline Säilörehun hinta 2 & 0,58 & 0,62 & 0,74 & 0,67 & 1,02 & 0,95 & 0,043 & $*$ & & \\
\hline \multicolumn{11}{|l|}{ C2-tukialue } \\
\hline Säilörehun hinta 1 & 0,32 & 0,23 & 0,48 & 0,43 & 0,93 & 0,85 & 0,014 & $*$ & & \\
\hline Säilörehun hinta 2 & 0,72 & 0,75 & 0,88 & 0,81 & 1,16 & 1,09 & 0,043 & $*$ & & \\
\hline
\end{tabular}

${ }^{1)} \mathrm{o} \mathrm{p}<0,10 ; * \mathrm{p}<0,05 ; * * \mathrm{p}<0,01 ; * * * \mathrm{p}<0,001 .{ }^{2)}$ Keskiarvon keskivirhe (Standard error of mean).

Rypsilisän antaminen alensi tuotannon taloudellista ylijäämää verrattuna vaihtoehtoon, jossa rypsilisää ei annettu. Poikkeuksen muodosti ryhmä, jossa väkirehua oli 30 prosenttia dieetistä ja säilörehu hinnoiteltiin muuttuvien kustannusten perusteella. Rypsilisän vaikutus ei kuitenkaan muodostunut tilastollisesti merkittäväksi missään vaihtoehdossa. Rypsilisä ei tämän tutkimuksen perusteella lisää lihasonnin kasvatuksesta saatavaa ylijäämää.

\section{Johtopäätökset}

Sonnien kasvu oli nopeinta eniten väkirehua saaneilla eläimillä. Dieetin väkirehuprosentin pienentäminen hidasti eläinten kasvunopeutta ja pidensi kasvatusaikaa. Rypsilisäys ei vaikuttanut merkitsevästi tuotantotuloksiin. Tämän tutkimuksen perusteella myös maitorotuiset lihanaudat voivat saavuttaa suuria teuraspainoja ilman ruhojen rasvoittumisongelmaa. Väkirehutasojen vaikutuksesta sonnien kasvuun ei voida tehdä tämän kokeen perusteella vielä lopullisia johtopäätöksiä. Alustavat tulokset koesarjan toisista kokeista näyttävät nimittäin olevan jossain määrin ristiriitaisia tässä artikkelissa esiteltyjen kasvutulosten kanssa. Tarkempia tuloksia eri väkirehutasojen ja väkirehun koostumuksen vaikutuksista lihanautojen loppukasvatuksessa saadaan koko koesarjan tulosten valmistuessa vuoden 2004 aikana.

Väkirehun osuuden lisääminen lihasonnien dieetissä näyttää lisäävään tuotannosta saatavaa ylijäämää. Nykyinen maatalouspolitiikka on kuitenkin luonut tilanteita, jossa säilörehua on myyty erittäin edullisesti. Jos naudanlihantuottajalla on mahdollisuus hankkia tällaista edullista säilörehua (alle $0,02 \mathrm{cnt} /$ kilo), väkirehun osuutta ruokinnassa ei ole järkevää nostaa kovin korkeaksi. Rypsilisän antamiselle ei näyttäisi tämän tutkimuksen tulosten perusteella olevan taloudellisia perusteita.

\section{Kirjallisuus}

Aronen, I. 1990. Barley protein and rapseed meal as protein supplemnts for growing cattle. Acta Agric. Scand. 40: $297-307$. 
Aronen, I. 1991. Influence of frequency and accuracy of supplement feeding of rumen fermentation, feed intake, diet digestion and performance of growing cattle. 1. Studies with growing bulls fed grass silage ad libitum. Anim. Feed Sci. Technol. 34: 49 - 65.

Aronen, I., Toivonen, V., Ketoja, E. \& Öfversten, J. 1992. Beef production as influenced by stage of maturity of grass for silage and level and type of supplementary concentrates. Agric. Sci. Fin. 1, 5: 441-460.

Huhtanen, P. 1998. Sonnia ei pidä kasvattaa sian rehuilla. Lihatalous 56, 1: 24-25.

Huhtanen, P. \& Jaakkola, S. 1994. Influence of grass maturity and diet on ruminal dry matter and neutral detergent fibre digestion kinetics. Archives of Animal Nutrition 47, 2: 153-167.

Huhtanen, P., Poutiainen, E. \& Mikkola, T. 1985. The effect of supplementation of grass silage with rapseed meal or Gasol-treated barley on the performance of growing cattle. J. Agric. Sci. Fin. 57: 75 - 84.

Joki-Tokola, E. 1996. Rankista ja rypsistä ei sonnien säilörehuruokinnassa ollut hyötyä. Koetoiminta ja käytäntö 53: 52.

Joki-Tokola, E. 1991. Lihaluurehujauho ja rypsirouhe sonnien valkuaisrehuna. Koetoiminta ja käytäntö 48: 64.

Keulen, J. van \& Young, B.A. 1977. Evaluation of acid-insoluble ash a marker in ruminant digestibility studies. J. Anim. Sci. 44: 282-287.

MMM. 2003. Hakuopas 2003. Maa- ja metsätalousministeriö. Helsinki. 149 s.

Pihamaa, P., Pietola, K. 2001. Lihanaudan kasvatuksen optimointi. MTT Taloustutkimus (MTTL), selvityksiä 7/2001: 43 p.

Ryhänen, M., Sipiläinen, T., Seppälä, R., Rinne, M., Huhtanen, P. \& Suokannas, A. 2002. Nurmirehua entistä edullisemmin. In: toim. Oiva Niemeläinen, Mari Topi-Hulmi. Nurmirehun kilpailukyvyn parantaminen tutkimusohjelman päätösseminaari 18.4.2002. Suomen Nurmiyhdistyksen julkaisu 17: p. 111-121.

\section{Liite 1.}

Taulukkoon 1. on kerätty laskelmissa käytetyt tärkeimmät panosten ja tuotosten hinnat sekä tuet.

Taulukko 1. Tuet ja hinnat

\begin{tabular}{lcr}
\hline Panosten hinnat & yks. & a' yks. \\
\hline Ohra & $\mathrm{kg}$ & 0,12 \\
Rypsirouhe & $\mathrm{kg}$ & 0,23 \\
Kivennäinen & $\mathrm{kg}$ & 0,48 \\
Säilörehu täysi tuotanto- & & \\
kustannus (hinta 1) & $\mathrm{kg}$ & 0,059 \\
Säilörehu muuttuvat & & \\
kustannukset (hinta 2) & $\mathrm{kg}$ & 0,037 \\
Vasikan hinta (- 50 kg) & eläin & 160 \\
Eläinpääoman korko & $\%$ & $4 \%$ \\
Liikepääoman korko & $\%$ & $4 \%$ \\
\hline
\end{tabular}

Lihan hintaan on tehty laskelmissa eläinkohtaiset teurastuloksista riippuvat korjaukset

\section{Koko kasvatuskausi}

Tuloksia laskettaessa alkukasvatuskauden osalta oletettiin kaikille sonneille sama dieetti. Tulokset on esitetty, jotta nähtäisiin lihasonnin kasvatuksesta koko kasvatusperiodin aikana saatava ylijäämä.

Taulukko 2. Taloudellinen ylijäämä sonnia kohti ternivasikasta teurastukseen.

\begin{tabular}{|c|c|c|c|c|c|c|c|c|c|c|}
\hline \multirow{2}{*}{$\begin{array}{l}\text { Väkirehu taso (V) } \\
\text { Rypsilisä (L) }\end{array}$} & \multicolumn{2}{|c|}{$30 \%$ dieetistä } & \multicolumn{2}{|c|}{$50 \%$ dieetistä } & \multicolumn{2}{|c|}{$70 \%$ dieetistä } & \multirow[b]{2}{*}{$\mathrm{S} \mathrm{EM}^{2}$} & \multicolumn{3}{|c|}{ Merkitsevyys ${ }^{1}$} \\
\hline & Ei lisää & Lisä & Ei lisäää & Lis ä & Ei lisää & Lisä & & $\mathbf{V}$ & $\mathbf{L}$ & $\mathbf{V} * \mathbf{L}$ \\
\hline \multicolumn{11}{|l|}{ B-tukialue } \\
\hline Säilörehun hinta 1 & 209,41 & 175,47 & 261,86 & 244,54 & 399,44 & 373,12 & 5,72 & $*$ & & \\
\hline Säilörehun hinta 2 & 361,7 & 376,42 & 402,91 & 376,73 & 473,84 & 451,79 & 15,3 & & & \\
\hline \multicolumn{11}{|l|}{ C2-tukialue } \\
\hline Säilörehun hinta 1 & 262,71 & 228,77 & 311,15 & 293,83 & 444,87 & 418,55 & 5,72 & $*$ & & \\
\hline Säilörehun hinta 2 & 415 & 429,72 & 452,2 & 426,03 & 519,27 & 497,22 & 15,3 & & & \\
\hline
\end{tabular}

1) o $\mathrm{p}<0,10 ; * \mathrm{p}<0,05 ; * * \mathrm{p}<0,01 ; * * * \mathrm{p}<0,001 .{ }^{2)}$ Keskiarvon keskivirhe (Standard error of mean). 